The Chicano Generation 
The publisher gratefully acknowledges the generous support of the Fletcher Jones Foundation Humanities Endowment Fund of the University of California Press Foundation. 


\title{
The Chicano Generation
}

Testimonios of the Movement

\author{
Mario T. García
}

\section{ㅁ}


University of California Press, one of the most distinguished university presses in the United States, enriches lives around the world by advancing scholarship in the humanities, social sciences, and natural sciences. Its activities are supported by the UC Press Foundation and by philanthropic contributions from individuals and institutions. For more information, visit www.ucpress.edu.

University of California Press

Oakland, California

(C) 2015 by The Regents of the University of California

Library of Congress Cataloging-in-Publication Data

García, Mario T., author.

The Chicano generation : testimonios of the movement / Mario T. García.

pages $\mathrm{cm}$

Includes bibliographical references and index.

ISBN 978-0-520-28601-6 (cloth : alk. paper)-ISBN 0-520-28601-4 (cloth : alk. paper)-ISBN 978-0-520-28602-3 (pbk. : alk. paper)-ISBN 0-52O28602-2 (pbk. : alk. paper)-ISBN 978-0-520-96136-4 (ebook)-ISBN 0-520-96136-6 (ebook)

1. Chicano movement-California-Los Angeles. 2. Ruiz, Raul, 1940- 3. Arellanes, Gloria, 1946- $\quad$ 4. Muñoz, Rosalio, 1946- I. Title. E184.M5G374 2015 $305.868^{\prime} 72079494-\mathrm{dc} 23$ 2014033778

Manufactured in the United States of America

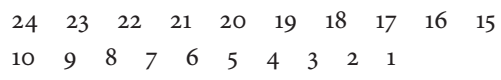

In keeping with a commitment to support environmentally responsible and sustainable printing practices, UC Press has printed this book on Natures Natural, a fiber that contains $30 \%$ post-consumer waste and meets the minimum requirements of ANSI/NISO Z39.48-1992 (R 1997) (Permanence of Paper). 
To Ramón Eduardo Ruiz, who believed in me 
This page intentionally left blank 